\title{
Аналіз наявних інструментів оцінювання впливу фізичної терапії на осіб з хворобою Паркінсона
}

\author{
УДК 616.858:316.614+613 \\ В. Брушко, Р. Баннікова, А. Ковельська
}

Національний університет фізичного виховання і спорту України, Київ, Україна

Резюме. Правильний і обґрунтований вибір інструментальних методів оцінювання функціонального стану пацієнта є обов'язковою умовою адекватної фізичної терапії. Особливе місце цей аспект займає в системі нейрореабілітації пацієнтів з хворобою Паркінсона в Україні, оскільки на сьогодні кількість осіб, що потребують систематичної фізичної терапії, сягає 23900 тис. Наростаюча маніфестація моторних і немоторних симптомів при хворобі Паркінсона, від яких часто вирішальною мірою залежить тяжкість стану пацієнта, негативно впливає на якість його життя. Наявні функціональні порушення, які $є$ самостійними проявами хвороби Паркінсона, вимагають специфічного підходу до комплексного інструментального дослідження цих порушень для визначення диференційно-діагностичних критеріїв та оцінювання впливу фізіотерапевтичного втручання. Мета. Проаналізувати наявні інструменти оцінювання впливу фізичної терапії на осіб з хворобою Паркінсона. Методи. Теоретичний аналіз та узагальнення зарубіжних даних спеціальної науково-методичної літератури з питань застосування інструментів оцінювання при хворобі Паркінсона та їх інформативності і надійності у фізичній терапії. Результати. Представлені дані свідчать, що ефективність запроваджених заходів фізичної терапії при хворобі Паркінсона залежить від правильно підібраних інструментів оцінювання, які дозволяють оцінити моторні і немоторні проблеми через призму життєдіяльності і якості життя пацієнта. Основним інструментом оцінювання для вирішення цього питання вважається Уніфікована рейтингова шкала хвороби Паркінсона MDS-UPDRS, яка дозволяє об'єктивно оцінити моторні і немоторні аспекти життя пацієнта і його рухову активність. Оскільки наявні моторні й аксіальні рухові порушення негативно впливають на повсякденну функціональну активність пацієнта, для верифікації цих порушень пропонують використовувати тест для оцінювання часу підйому і ходьби (Timed Up and Go (TUG)); тест з подвійним завданням (Dual-Task TUG (TUG-DT)) та шкалу рівноваги Берга (Berg Balance Scale (BBS)). Але виходячи з того, що ці тести недостатньо чутливі до невеликих змін у рухливості при хворобі Паркінсона, особливо на середніх і пізніх стадіях захворювання, їх доцільно поєднувати з одним із кількісних тестів для оцінювання ходьби: 10-метровим тестом ходьби (10 Meter Walk Test (10MW)) та 6-хвилинним тестом ходьби (Six Minute Walk Distance (6MWT)). Поняття «життєдіяльність» включає в себе не тільки переміщення, ї̈ оцінювання має бути доповнено аналізом ступеня впливу наявних порушень на повсякденну діяльність, тобто на якість життя пацієнта. Найбільш інформативними інструментами для проведення цього аналізу є універсальні і специфічні при хворобі Паркінсона опитувальники з метою оцінювання стану здоров'я SF-36, EuroQOL (EQ-5D) і PDQ-39 (The Parkinson's Disease Questionnaire). Результати аналізу та узагальнення даних науково-методичної літератури дають підставу встановити, що маніфестація порушень та їх варіабельність при хворобі Паркінсона стають серйозною проблемою у досягненні кінцевого результату запроваджених заходів фізичної терапії на всіх стадіях захворювання. Використання в комплексі стандартної експертно-реабілітаційної діагностики спеціальних інструментів оцінювання дозволяє об'єктивізувати оцінювання клінічної інформації та стимулює розроблення особистоорієнтованих реабілітаційних стратегій із застосуванням заходів фізичної терапії, спрямованих на покращення якості життя пацієнтів з хворобою Паркінсона.

Ключові слова: хвороба Паркінсона, фізична терапія, якість життя, інструменти оцінювання, достовірність, надійність, валідність. 


\section{Analysis of available tools to assess the impact of physical therapy on persons with Parkinson's disease}

\section{Brushko, R. Bannikova, A. Kovelska}

Abstract. Correct and reasonable choice of instrumental methods for evaluation of patient's functional state is a prerequisite for adequate physical therapy. This aspect occupies a special place in the Ukrainian system of neurorehabilitation of patients with Parkinson's disease (PD) because the number of persons in need of systematic physical therapy reaches 23900 thousand. The increasing manifestation of motor and non-motor symptoms in PD, which often decisively determine the severity of a patient's condition, negatively affects their quality of life. Therefore, existing functional disorders, independent manifestations of PD, require a specific approach to a comprehensive instrumental study of these disorders to determine the differential diagnostic criteria and assess the impact of physical therapy intervention. The objective of the study is to analyze the available tools for evaluating the effect of physical therapy on persons with Parkinson's disease. Methods. To achieve this goal, we applied the following research methods: the theoretical analysis and generalization of foreign data of special scientific and methodological literature on using assessment tools in PD and their informativeness, and reliability in physical therapy. Results. The presented data show that the effectiveness of physical therapy interventions for PD depends on properly selected assessment tools that assess motor and non-motor problems through the prism of the patient's vital activities and quality of life. The Uniform PD Rating Scale MDSUPDRS is considered the primary assessment tool to address this issue, which allows an objective assessment of the motor and non-motor aspects of a patient's life and motor activity. Since the existing motor and axial motor impairments negatively affect the patient's daily functional activities, the Timed Up and Go (TUG); Test for Mobility, Balance, and Motor Activities (TUG) Dual-Task TUG (TUG-DT) and the Berg Balance Scale (BBS) are suggested for verifying these impairments. Because these tests are not sensitive enough to small changes in mobility in PD, especially in the middle and late stages of the disease, it is reasonable to combine them with one of the quantitative walking tests, such as the 10 Meter Walk Test (10MW) and the Six-Minute Walk Distance (6MWT). The concept of vital activity includes not only movement but its assessment should be supplemented by analysis of the degree of influence of the existing impairments on daily activities, i.e., on the patient's quality of life. The most informative tools for this analysis are the universal and PD-specific health assessment questionnaires SF-36, EuroQOL (EQ-5D), and PDQ-39 (The Parkinson's Disease Questionnaire). The results of the analysis and generalization of the scientific and methodological literature data give grounds to establish that the manifestation of disorders and their variability in PD become a serious problem in achieving the final result of physical therapy measures at all stages of the disease. The use of special assessment tools in the complex of standard expert-rehabilitation diagnostics allows to objectify the assessment of clinical information and stimulates the development of person-oriented rehabilitation strategies with the use of physical therapy means, aimed at improving the quality of life of PD patients.

Keywords: Parkinson's disease, physical therapy, quality of life, assessment tools, validity, reliability, validity.

Постановка проблеми. Правильний і обгрунтований вибір інструментальних методів оцінювання функціонального стану пацієнта $\epsilon$ обов'язковою умовою адекватної фрізичної терапії. Особливе місце цей аспект займає в українській системі нейрореабілітації пацієнтів 3 прогресуючими захворюваннями центральної нервової системи (ЦНС), до яких належить хвороба Паркінсона (ХП), оскільки на сьогодні кількість осіб, що потребують спеціалізованої систематичної фрізичної терапії, сягає 23900 тис., при цьому методологія і можливості проведення корекційно-реабілітаційного відновлення значно відстають від їх потреб [2].

Здебільшого вважається, що ХП переважно вражає моторну сферу, руховими проявами якої $€:$ гіпокінезія, ригідність, тремор, порушення сте- реотипу ходьби й постуральної нестабільності, що вирішальною мірою визначає тяжкість стану функціональної мобільності пацієнта і якість його життя. Крім моторних симптомів, у клінічній картині ХП присутній широкий спектр і немоторних порушень, прояви яких з'являються вже на ранніх стадіях і наростають у міру прогресування захворювання - паралельно з посиленням рухових розладів, але деякі з них, такі як когнітивні розлади, з'являються на доклінічній стадії ХП, випереджаючи маніфестацію моторних симптомів паркінсонізму, негативно впливаючи на якість життя тематичних пацієнтів, призводячи до їх інвалідизації [2, 27].

У численних дослідженнях, проведених за останні роки [2, 9, 13], автори доходять висновку, що моторні та немоторні порушення служать 
самостійним проявом ХП і мають свій особливий патогенез. Це вимагає специфрічного підходу до комплексного інструментального дослідження таких порушень для визначення диоеренційнодіагностичних критеріїв та оцінювання впливу корекційно-відновного втручання, а також підбору диференційованих заходів фрізичної терапії, спрямованих на їх корекцію, що в кінцевому підсумку дозволить відтермінувати важку інвалідизацію і, відповідно, покращити якість життя (ЯЖ) пацієнтів [30].

Роботу виконано за планом кафедри фрізичної терапії та ерготерапії Національного університету фрізичного виховання і спорту України м. Києва на 2016-2020 рр. за темою 4.2 «Організаційні та теоретико-методичні основи фрізичної реабілітації осіб різних нозологічних, професійних та вікових груп» (номер держреєстрації 0116U001609) і за планом кафедри фрізичної терапії та ерготерапії Національного університету фрізичного виховання і спорту України м. Києва на 2021-2025 рр. за темою 4.1 «Відновлення фрункціональних можливостей, діяльності та участі осіб різних нозологічних, професійних та вікових груп» (номер держреєстрації 0121U107926).

Мета дослідження - проаналізувати наявні інструменти оцінювання впливу фрізичної терапії на осіб з ХП.

Методи дослідження: теоретичний аналіз та узагальнення зарубіжних даних спеціальної науково-методичної літератури з питань застосування інструментів оцінювання при ХП та їх інформативності і надійності у фрізичній терапії.

Результати дослідження. Фізична терапія при ХП - це багатоспрямований складний процес, структурувати який допомагає Міжнародна класифрікація фрункціонування, обмеження життєдіяльності та здоров'я - МКФ (International Classification of Functioning, Disability and Health (ICF)) [7, 14, 15].

Ведення тематичних пацієнтів вимагає ретельного вивчення стану пацієнта з точки зору всіх компонентів, що входять в МКФ: оцінювання змін структури тіла (наявність постуральних деформацій тулуба як частих ускладнень при ХП: синдром «Пізанської вежі», камптокормія, антеколліс та сколіоз); функцій, пов'язаних з рухом (розтягуваність м'язів, можливість активного скорочення м'язів, ступінь зміни м'язового тонусу, м'язова витривалість, рухливість у суглобах, наявність тремору, болю у м'язах тощо); активності й участі (спілкування, мобільність, побутове життя, самообслуговування, міжособистісні взаємодії та відносини тощо). Для верифрікації кожного з цих напрямів, описаних за допомогою МКФ, існують свої уніфріковані і спеціальні стандартизовані інструменти оцінювання (шкали, тести, опитувальники) [3, 19, 30].

Серйозними проблемами для успішної довгострокової фрізичної терапії осіб з ХП на всіх стадіях захворювання є приєднання до основних моторних проявів аксіальних рухових порушень у вигляді змін стереотипу ходьби та постуральної стійкості, від яких часто вирішальною мірою залежать тяжкість стану пацієнта і його фуннціональна мобільність та незалежність у повсякденному житті [2, 4, 8, 11]. Тому для цієї категорії пацієнтів необхідні такі інструменти оцінювання, які дозволяють оцінити проблеми моторних порушень через призму життєдіяльності (функціонування) й одночасно $€$ основним показником для оцінювання ефективності впливу фрізіотерапевтичного втручання.

Вибрати з безлічі запропонованих світовою практикою інструментів оцінювання при ХП найбільш адекватний (надійний, валідний і чутливий) варіант досить складно [4, 11, 15]. Протягом останніх років практично всі багатоцентрові клінічні дослідження присвячені порівнянню ефективності різних засобів та методів фрізичної терапії, що поряд із традиційними клінічними критеріями визначення їх ефрективності включають оцінювання якості життя та критерій соціальної адаптації пацієнта [11, 15].

Ми проводили інформаційний пошук у базах даних PubMed, PEDro, Google Scholar для виявлення оглядових і експериментальних нефармакологічних досліджень до 2021 р., які включали інструменти оцінювання при ХП. Із проаналізованих 42 інструментів оцінювання ми відібрали й описали ті, які найбільш цитуються у зарубіжній науковій літературі. Словами пошуку були: ХП, рейтинг методів оцінювання при ХП, спеціалізовані шкали, стандартні фрункціональні тести, опитувальник якості життя, достовірність, надійність, інформативність.

Основним цитованим інструментом оцінювання динаміки позитивних змін фрункціональної мобільності в процесі застосування фрізіотерапевтичних заходів при ХП у зарубіжній літературі $\epsilon$ Уніфрікована рейтингова шкала XП MDS-UPDRS $[2,5,9]$. Ця шкала застосовується в багатьох дослідженнях нефармакологічного втручання. Час, необхідний для заповнення MDS-UPDRS, становить приблизно 40-50 хв. Цей опитувальник складається з чотирьох розділів і 65 пунктів запитань, які оцінюють: немоторні аспекти повсякденного життя (чотири пункти), моторні аспекти повсякденного життя (13 пунктів), рухову активність пацієнта і терапевтичні ускладнення 
(11 пунктів) [9]. Кожне запитання має 5-бальну градацію для вибору, засновану на концепції шкали Лікерта, за винятком IV розділу, де надаються два варіанти відповіді, що оцінюються в 0 або 1 бал. Оцінка фрормується шляхом підсумовування балів за всіма елементами в різних підрозділах, а потім результати складаються зі стандартним діапазоном від 0 до 147, де 147 означає максимальну (повну) інвалідизацію пацієнта. Достовірність і відтворюваність інформації, отриманої за допомогою цього вимірювального інструмента, було доведено й описано в різних дослідженнях [17]. Найкраще це простежується при оцінюванні повсякденної діяльності і рухової активності пацієнта (розділи II, III) [17] і меншою мірою для терапевтичних ускладнень (розділ IV). Шкала MDS-UPDRS достовірна, надійна і має досить високу чутливість навіть тоді, коли відповіді надаються членом сім'ї або опікуном. 3 основних недоліків при використанні MDS-UPDRS у контексті клінічних досліджень відзначено: тривалість часу для оцінювання; відсутність окремих балів для періодів «включення» $\mathrm{i}$ «виключення»; неможливість оцінити ступінь моторних порушень і точність рухових симптомів на ранніх стадіях ХП, оскільки запитання у III розділі пов'язані 3 прогресуванням захворювання; неможливість виявлення позитивних змін ефективності лікування та фрізіотерапевтичного втручання, спрямованого на певні рухові компоненти [17].

Наступними найбільш цитованими інструментами оцінювання динаміки позитивних змін функціональної мобільності в процесі фрізіотерапевтичного втручання при ХП є клінічно обгрунтовані тести, такі як: тест для оцінювання часу підйому і ходьби (Timed Up and Go (TUG)); тест $з$ подвійним завданням (Dual-Task TUG (TUG-DT)); 10-метровий тест ходьби (10 Meter Walk Test (10MW)); 6-хвилинний тест ходьби (Six Minute Walk Distance (6MWT)); шкала рівноваги Берга (Berg Balance Scale (BBS)) [8, 12, 13, 21]. У 19 дослідженнях (72,5 \%) клінічно обгрунтовані тести застосовували як інструменти вимірювання, у шести (15\%) - застосовували комбінацію тестів з методом кількісного оцінювання ходьби, а у двох $(7,5 \%)$ - лише методи кількісного оцінювання ходьби.

Тест для оцінювання часу підйому і ходьби (Timed Up and Go (TUG)) - стандартний тест, який використовують для оцінювання мобільності, рівноваги та рухової активності при ХП [3]. Цей тест включає виконання завдання, при якому пацієнт повинен піднятися зі стандартного стільця, пройти 3 м у зручному для нього темпі, розвернутися та повернутися назад до стільця і сісти
[3]. Відлік часу починається зі словесної інструкції «йти» і зупиняється, коли пацієнт повертається у вихідне положення. Оцінка складається з часу, витраченого на виконання тестового завдання, в секундах. Ефективність тесту оцінюється за шкалою від 1 до 5 балів, де 5 - «вкрай задовільне функціонування» (ризик до частих падінь).

Результати проведених досліджень B. R. Bloem et al. [3] при застосуванні TUG для тематичних пацієнтів виявили відмінність між етапами корекційно-відновного лікування з помірно сильною кореляцією $(r=0,74 ; n=12 ; p=0,003)$ між фразами «включення» $\mathrm{i}$ «виключення». Чутливість і специфічність для визначення ризику падінь становила $87 \%$. У досліджуваних пацієнтів, яким потрібно було більше 15 с для завершення тесту, визначався високий ризик до падінь. Дані проведених досліджень G. Verheyden et al. [29] також підтвердили достовірність і надійність тесту TUG для пацієнтів з ХП, але основним недоліком у контексті клінічних досліджень було відзначено неможливість фріксувати функціональний статус пацієнта в його оточенні і повсякденній діяльності.

Тест з подвійним завданням (Dual-Task TUG (TUG-DT)) $є$ доповненням до стандартного тесту Timed Up and Go, де пацієнт при виконанні тестового завдання повинен рахувати трійками назад від випадкового числа (від 20 до 100) або тримати чашку, наповнену водою [3]. Ефективність тесту оцінюється за шкалою від 1 до 5 балів, де 5 - «вкрай задовільне фрункціонування» (ризик до частих падінь).

M. Hofheinz et al. [7] у своїх дослідженнях відзначають високий рівень надійності TUG-DT, який, на їх думку, може бути більш корисним, ніж TUG, для оцінювання ефективності корекційно-відновного лікування. Дослідники відзначили сильну кореляцію між TUGman та BBS $(r=-0,72)$ і між TUGcog та BBS $(r=-0,66)$, що свідчить про високий критерій валідності; хороша надійність повторного тестування TUGman $(r(\mathrm{~T} 1-\mathrm{T} 2)=0,97 \mathrm{i} r(\mathrm{~T} 1-\mathrm{T} 3)=0,98)$ та TUGcog $(r(T 1-T 2)=0,98$ і r $(T 1-T 3)=0,98)$. Середній час, необхідний для виконання TUGman, становив 11,6 с (95\% Cl 11,2-11,9); середній час, необхідний для виконання TUGcog, становив 9,8 с $(95 \% \mathrm{Cl} 9,5-10,2)$. Слід зазначити, що хоча дослідники довели надійність і валідність тесту TUG-DT $з$ урахуванням статі і тест часто застосовується в дослідженнях, клінічно тест TUG-DT не оцінювався.

Шкала рівноваги Берга (Berg Balance Scale (BBS)), на думку багатьох дослідників [8, 12, $13,21], \epsilon$ золотим стандартом оцінювання статичної і динамічної рівноваги у пацієнтів з ХП. 
Шкала складається з 14 завдань, які пов'язані з балансом у діапазоні від сидіння, вставання 3 положення сидячи до стояння на одній нозі [8, 12]. Час, необхідний для проведення тестування, становить 15-20 хв. Кожне завдання має 5-бальну градацію для оцінювання на підставі здатності пацієнта виконати самостійно 14 завдань i/або зробити це відповідно до певних вимог часу i відстані. Оцінка формується шляхом підсумовування балів за всіма компонентами, а потім результати складаються зі стандартним діапазоном від 0 до 56 балів. Чим вище показник, тим вища якість виконання завдання [12, 21].

Оцінка BBS показала значущу кореляцію 3 показниками рухової активності та повсякденної діяльності пацієнтів з ХП, що підтверджується результатами досліджень С. А. С. Prinsen et al. [21]. Оцінка BBS, за даними дослідників, суттєво корелює з показниками моторної діяльності (моторний бал MDS-UPDRS: $r=-0,58$; $p<0,005)$, TUG ( $r=0,55 ; p<0,005)$. Більш низькі бали за BBS (вказуючи на більший дефіцит балансу) коригували з більш високими балами за шкалою MDS-UPDRS (вказуючи на більшість моторних або функціональних порушень). Доведено, що показники BBS нижче або вище 45 балів, відповідно, відокремлюють пацієнтів з ризиком до падінь від тих, у кого немає цього ризику. Залежно від значення цього порогового показника чутливість і специфічність виявлення осіб з ризиком до падінь значно варіює: пороговий показник 40 балів дає чутливість і специфрічність, що дорівнюють 45 і $96 \%$ відповідно, в той час як пороговий показник 50 балів робить показники чутливості і специярічності рівними відповідно 85 і 73 \% [21].

10-метровий тест ходьби (10 Meter Walk Test $(10 M W))$ і 6-хвилинний тест ходьби (Six Minute Walk Distance (6MWT)) широко використовуються у фрізичній терапії для оцінювання швидкості ходьби і визначення фрункціонального статусу пацієнта з ХП. У проаналізованих нами клінічних дослідженнях ці тести застосовували у поєднанні 3 іншими інструментами оцінювання [7, 11, 14, 15].

A. P. C. Loureiro et al. [15] досліджували взаємозв'язок між 10-метровим тестом ходьби (10 Meter Walk Test (10MW)) і показниками балансу при частих падіннях при ХП. Було встановлено позитивну кореляцію між 10-MWT і загальним балом Mini-BESTest (рівновага) (rho $=0,73 ; p<0,001$ ), а також 3 кожним компонентом Mini-BESTest: попереджуючими корективами пози (rho $=0,71 ;$ p $<0,001)$, реакціями пози (rho $=0,49 ; p<0,001)$, сенсорною орієнтацією (rho $=0,44 ; p<0,002)$ і динамічною ходою (rho $=0,69 ; p<0,001)$. За даними дослідників, тест $10 \mathrm{MW}$ має надійність повторного тестування $(0,75-0,98)$ від помірного до високого рівня значень мінімального виявлення змін 0,18 і 0,25 м/с [15].

E. Kobayashi et al. [14] у своїх дослідженнях проводили клінічну апробацію застосовування тесту Six Minute Walk Distance (6MWT) у поєднанні 3 іншими інструментами оцінювання для пацієнтів з ХП середнього ступеня тяжкості. За отриманими даними, TUG ( $r=-0,68, p<0,01)$ i $10 \mathrm{MW}(r=-0,65, \mathrm{p}<0,01)$ достовірно корелювали з 6MWT (340,8 \pm 110,9м). Множинний регресійний аналіз із віком, стадією HY, TUG і 10MW вказує на значний ступінь варіабельності результатів 6MWT ( $r=0,77, p<0,001)$. TUG $(\beta=-0,47, p<0,01)$ i $10 \mathrm{MW}(\beta=-0,4, p<0,01)$ незалежно корелювали з результатами 6MWT, тим самим підтверджуючи конвергентну валідність і клінічну значущість застосування 6MWT для пацієнтів з ХП.

Основним критерієм і більш точним фрактором есрективності застосування фрізіотерапевтичних заходів $\epsilon$ якість життя (ЯЖ) пацієнта $[2,26]$. У клінічних дослідженнях зустрічається велика кількість інструментів оцінювання ЯЖ при ХП: шкала PDQ-39 (The Parkinson's Disease Questionnaire), шкала PD-QUALIF, опитувальник PDQL, шкала EuroQol-5D (EQ-5D), шкала PROMIS-29, опитувальник оцінки стану здоров'я (SF-36), профріль впливу захворювання (SIP), Ноттингемський профріль здоров'я (the Nottingham Health Profile - NHP) та шкала благополуччя (Quality of Well-Being - QWB) [24]. За даними авторів [17, 24, 26], усі вони мають різні характеристики - надійність, валідність, навантаження на респондента і дослідника, альтернативні (скорочені) форми і перекладні варіанти [26].

Найбільш цитованими інструментами оцінювання динаміки змін ЯЖ у процесі фрізіотерапевтичного втручання при ХП у зарубіжній літературі $\epsilon$ опитувальник оцінки стану здоров'я SF-36, EuroQOL (EQ-5D) i PDQ-39 (The Parkinson's Disease Questionnaire) [15, 17, 19].

Опитувальник SF-36 складається 336 запитань, оцінюючи вісім аспектів здоров'я (субшкал) - фрізичне фрункціонування, рольові обмеження через фрізичні проблеми, фрізичний біль, загальне сприйняття здоров'я, енергійність, соціальне функціонування, рольові обмеження через емоційні проблеми і психічне здоров'я [16]. У кожному запитанні $€$ 5-бальна градація для вибору, заснована на концепціях шкали Лікерта. Час, необхідний для заповнення SF-36, становить приблизно 10 хв. Оцінка формується шля- 
хом підсумовування балів за всіма елементами в різних підрозділах, а потім результати складаються зі стандартним діапазоном від 0 до 100, де оцінка 100 визначає найвищий стан здоров'я [16]. Достовірність і відтворюваність інформації, отриманої за допомогою цього вимірювального інструмента, були доведені й описані в різних дослідженнях [16]. Найкраща динаміка змін ЯЖ при ХП простежується при оцінюванні фрізичного і психічного здоров'я, найгірша - при оцінюванні соціальної діяльності [17]. Опитувальник SF-36 достовірний, надійний та чутливий до змін у виборі пацієнтів з ХП. Його чутливість досить висока навіть тоді, коли відповіді надають члени сім'ї [17].

Результати досліджень Р. Martinez-Martin et al. [17] підтвердили отримання восьми (субшкал) балів за шкалою SF-36, і їх надійність у цілому була гарною ( $>$ або $=0,74$ у всіх випадках, крім одного). Однак дослідники виявили значні обмеження, які ставлять під сумнів значимість чотирьох субшкал, а саме їх здатність виявляти достовірні зміни в клінічних дослідженнях (ефекти статі 19,6-46,2 \%). Два сумарних показники SF-36 не були визнані достовірними показниками фрізичного та соціального здоров'я.

Опитувальник EuroQOL (EQ-5D) - це стандартизована методика оцінювання стану здоров'я, розроблена групою EuroQOL як простий універсальний метод для широкого спектра умов і вибірки [16, 17]. Час, необхідний для заповнення анкети, становить приблизно 18 хв. Ця шкала дозволяє оцінювати п'ять аспектів здоров'я - мобільність, здатність до самообслуговування, щоденну активність, біль/дискомфорт і тривогу/депресію. Пацієнт оцінює свій стан за кожним параметром за 3-бальною порядковою шкалою вибору. Це супроводжується візуальною аналоговою шкалою (VAS) для самооцінки власного здоров'я від 0 (найгірший стан здоров'я) до 100 (найкращий стан здоров'я) [16, 17]. EQ-5D відрізняється від інших інструментів оцінювання ЯЖ своєю простотою і доступністю для пацієнта [16, 17]. У міжнародному дослідженні з оцінювання якості даних було показано відсутність істотних відмінностей у валідності і відтворюваності при зборі інформації за допомогою SF-36 і EQ-5D [16, 17].

Опитувальник PDQ-39 (The Parkinson's Disease Questionnaire) включає 39 запитань, які можна розділити на вісім розділів: мобільність (10 запитань); повсякденна активність (6 запитань); емоційне благополуччя (6 запитань); стигми (4 запитання); соціальна підтримка (3 запитання); когнітивні фрункції (4 запитання); спілкування (3 запитання) і тілесний дискомфорт (3 запитан- ня) $[16,17]$. У кожному запитанні є 5-бальна градація для вибору, заснована на концепціях шкали Лікерта. Час, необхідний для заповнення PDQ-39, становить приблизно 15-20 хв. Оцінка формується шляхом підсумовування балів за всіма елементами в різних підрозділах, а потім результати складаються зі стандартним діапазоном від 0 до 195, де найвищі бали вказують на погіршення стану здоров'я. Опитувальник PDQ-39 достовірний, надійний та чутливий до змін у виборі пацієнтів з ХП. Результати досліджень P. Martinez-Martin et al. [16, 17] підтвердили отримання восьми (субшкал) балів за шкалою PDQ-39, іï валідність та надійність. Також дослідники визначили значну кореляцію PDQ-39 з MDS-UPDRS (частина II) щодо мобільності, повсякденної активності, емоційного благополуччя, соціальної підтримки і фрізичного дискомфорту ( $r s=0,300 \sim 0,375)$. Це свідчить про те, що рухові труднощі повсякденного життя у пацієнтів 3 ХП сприяють погіршенню ЯЖ у фрізичній, психологічній та соціальній сорерах.

Дискусія. Наукові дослідження в нейрореабілітації не можливі без використання тих чи інших методів об'єктивізації клінічного обстеження пацієнта. В Україні останнім часом, 3 урахуванням національних та культурних особливостей, успішно проводиться адаптація універсальних і специфрічних інструментів оцінювання (шкал, тестів, опитувальників), що широко застосовуються в реабілітації пацієнтів неврологічного профрілю. ХП - поширене гетерогенне нейродистрофрічне захворювання, на яке страждає $1 \%$ населення від 40 до 60 років, що вимагатиме нових підходів до своєчасної діагностики та високоефективних методів корекційно-відновного лікування цього неврологічного розладу. ХП, як і інші нейродегенеративні захворювання, характеризується прогресуючим перебігом із закономірною зміною стадій - від латентної до розгорнутої. Виявлення поєднання різноманітних симптомів та особливостей їх проявів у кожного пацієнта є основою для побудови правильної тактики корекційно-відновного лікування. Оцінювання як основа для аналізу проблем пацієнта і розроблення ефективного лікування повинне проводитися постійно. Процес оцінювання проблем пацієнта включає розпізнавання, визначення причини та вимірювання. Перелік проблем пацієнта будується відповідно до МКФ: порушення структури і/або фрункції, активність, участь. Одним із принципів ефективної та успішної фрізичної терапії пацієнтів з ХП є стандартизоване оцінювання динаміки стану та ступеня функціонування пацієнта з використанням шкал, тестів 
та опитувальників. У клінічній стадії ХП основним інструментом об'єктивізації ступеня тяжкості симптоматики є Уніфрікована рейтингова шкала оцінювання XП (UPDRS). Вона має сильну кореляцію з іншими валідними шкалами, що застосовуються для оцінювання симптомів при ХП: тестом для оцінювання часу підйому і ходьби (Timed Up and Go (TUG)); тестом з подвійним завданням (Dual-Task TUG (TUG-DT)); 10-метровим тестом ходьби (10 Meter Walk Test (10MW)); 6-хвилинним тестом ходьби (Six Minute Walk Distance (6MWT)); шкалою рівноваги Берга (Berg Balance Scale (BBS)).

Аналіз результатів корекційно-відновного лікування повинен проводитися за такими параметрами: відновлення неврологічних фрункцій, рівень соціально-побутової адаптації та психоемоційний стан. Необхідно відзначити, що у перелічених вище шкалах та тестах домінує локальна спрямованість і недостатньо уваги приділяється соціальним та побутовим діям, а також відсутнє оцінювання ЯЖ. До шкал, що оцінюють соціальну дезадаптацію та ЯЖ при ХП, відносять: шкалу PDQ-39 (The Parkinson's Disease Questionnaire), шкалу PD-QUALIF, опитувальник PDQL, шкалу EuroQol-5D (EQ-5D), шкалу PROMIS-29, опитувальник оцінки стану здоров'я (SF-36), профріль впливу захворювання (SIP), Ноттингемський профріль здоров'я (the Nottingham Health Profile - NHP) та шкалу благополуччя (Quality of Well-Being - QWB), які мають різні характеристики - надійність, валідність, навантаження на респондента і дослідника, альтернативні (скорочені) фрорми і перекладні варіанти.

Таким чином, сучасні підходи до корекційно-відновного лікування ХП мають комплексний

\section{Література}

1. Гольдблат ЮВ. Основы реабилитации неврологических больных [Fundamentals of rehabilitation of neurological patients]. Санкт-Петербург: СпецЛит; 2017.767 с

2. Левин ОС. Экстрапирамидные расстройства, вчера, сегодня, завтра: сборник статей [Extrapyramidal disorders, yesterday, today, tomorrow: Collection of articles]. Москва: МЕДпресс-информ; 2018.408 с.

3. Bloem BR, Marinus J, Almeida Q, Dibble L, Nieuwboer A, Post B, et al. Measurement instruments to assess posture, gait, and balance in Parkinson's disease: critique and recommendations. Mov Disord. 2016;31(9):1342-55.

4. Downey CL, Brown JM, Jayne DG, Randell R. Patient attitudes towards remote continuous vital signs monitoring on general surgery wards: An interview stu-dy. Int J Med Inform. 2018;114:52-6.

5. Ekker MS, Janssen S, Seppi K, Poewe W, de Vries NM, Theelen T, et al. Ocular and visual disorders in Parkinson's disease: Common but frequently over-looked. Parkinsonism Relat Disord. 2017;40:1-10.

6. Forhan M, Gill SV. Obesity, functional mobility and quality of life. Best Pract Res Clin Endocrinol Metab. 2013;27(2):129-37.

7. Hofheinz M, Schusterschitz C. Dual task interference in estimating the risk of falls and measuring change: a comparative, psychometric study of four measurements. Clin Rehabil. 2010;24(9):831-42. характер. Одним із найбільш важливих проривів у нейрореабілітації останніх років стало впровадження в практику шкал, що дозволяє не тільки об'єктивізувати оцінювання клінічної інфрормації, підвищити контроль моторних та немоторних симптомів у пацієнтів з розгорнутими стадіями ХП, а й коригувати їх за допомогою заходів фрізичної терапії.

Висновки. Результати аналізу та узагальнення даних науково-методичної літератури дають підставу встановити, що маніфестація порушень та їх варіабельність при ХП стають серйозною проблемою у досягненні кінцевого результату запроваджених заходів фрізичної терапії на всіх стадіях захворювання, тому важливою $є$ правильна оцінка стадійності і характеру прогресування патологічного процесу. Використання в комплексі стандартної експертно-реабілітаційної діагностики спеціальних шкал, тестів та опитувальників дозволяє об'єктивізувати оцінювання клінічної інорормації та стимулює розроблення особистоорієнтованих реабілітаційних стратегій із застосуванням заходів фрізичної терапії, спрямованих на покращення ЯЖ пацієнтів з ХП.

Перспективи подальших досліджень. Враховуючи прогресивне старіння населення, що неминуче супроводжується збільшенням поширеності ХП, та відповідно підвищення витрат на лікування, використання інструментів оцінювання впливу заходів фрізичної терапії $€$ особливо важливим та створює перспективи для розроблення і впровадження нових технологій корекційно-відновного лікування, спрямованих на підвищення ступеня соціальної адаптації, покращення ЯЖ та відтермінування важкої інвалідизації пацієнтів з ХП.

8. Holden SK, Koljack CE, Prizer LP, Sillau SH, Miyasaki JM, Kluger BM Measuring quality of life in palliative care for Parkinson's disease: A clinimetric comparison. Parkinsonism Relat Disord. 2019;65:172-7.

9. Horváth K, Aschermann Z, Ács P, Deli G, Janszky J, Komoly S, et al Minimal clinically important difference on the Motor Examination part of MDSUPDRS. Parkinsonism Relat Disord. 2015;21(12):1421-6.

10. Horváth K, Aschermann Z, Kovács M, Makkos A, Harmat M, Janszky $\mathrm{J}$, et al. Minimal clinically important differences for the experiences of daily living parts of movement disorder society-sponsored unified Parkinson's disease rating scale. Mov Disord. 2017;32(5):789-93.

11. Jankovic J. Parkinson's disease: clinical features and diagnosis. J Neurol Neurosurg Psychiatry. 2018;79(4):368-76.

12. Keus S, Munneke M, Graziano M, Paltamaa J, Pelosin E, Domingos $\mathrm{J}$, et al. European physiotherapy guideline for Parkinson's disease [Internet] 1st ed. The Netherlands: KNGF/ParkinsonNet; 2014. 191 p. Available from: https://www.parkinsonnet.nl/app/uploads/sites/3/2019/11/eu_guideline_ parkinson_guideline_for_pt_s1.pdf

13. Kim SD, Allen NE, Canning CG, Fung VS. Postural instability in patients with Parkinson's disease. Epidemiology, pathophysiology and management. CNS Drugs. 2013;27(2):97-112. 
14. Kobayashi E, Himuro N, Takahashi M. Clinical utility of the 6-min walk test for patients with moderate Parkinson's disease. Int $\mathrm{J}$ Rehabil Res.2017:40(1):66-70.

15. Loureiro APC, Yamaguchi B, Israel V. Relationship of 10-Meter Walk Test to balance performance in Parkinson's disease patients as a predictor of falls [abstract]. In: 2018 International Congress 2018 Oct 5-9; Hong Kong. Mov Disord. 2018;33 (suppl 2).

16. Martinez-Martin P, Jeukens-Visser M, Lyons KE, Rodriguez-Blazquez C, Selai C, Siderowf A, et al. Health-related quality-of-life scales in Parkinson's disease: critique and recommendations. Mov Disord. 2019;26(13):2371-80.

17. Martinez-Martin P, Skorvanek M, Rojo-Abuin JM, Gregova Z, Stebbins GT, Goetz CG; members of the QUALPD Study Group. Validation study of the hoehn and yahr scale included in the MDS-UPDRS. Mov Disord. 2018;33(4):651-2.

18. Nonnekes J, Goselink RJM, Růžička E, Fasano A, Nutt JG, Bloem BR. Neurological disorders of gait, balance and posture: a sign-based approach. Nat Rev Neurol. 2018;14(3):183-9.

19. Nonnekes J, Ružicka E, Nieuwboer A, Hallett M, Fasano A, Bloem BR. Compensation strategies for gait impairments in Parkinson disease: a review. JAMA Neurol. 2019;76(6):718-25

20. Nonnekes J, Snijders AH, Nutt JG, Deuschl G, Giladi N, Bloem BR. Free-zing of gait: a practical approach to management. Lancet Neurol. 2015;14(7):768-78

21. Prinsen CAC, Vohra S, Rose MR, Boers M, Tugwell P, Clarke M, et al. How to select outcome measurement instruments for outcomes included in a «Core Outcome Set» - a practical guideline. Trials [Internet]. 2016 Sept;17:449. Available from: https://trialsjournal.biomedcentral.com/articles/10.1186/ s13063-016-1555-2.

22. Qamar MA, Harington G, Trump S, Johnson J, Roberts F, FrostE. Multidisciplinary Care in Parkinson's Disease. Int Rev Neurobiol. 2017;132:511-23.
23. Radder DLM, de Vries NM, Riksen NP, Diamond SJ, Gross D, Gold DR, et al. Multidisciplinary care for people with Parkinson's disease: the new kids on the block! Expert Rev Neurother. 2019;19(2):145-57.

24. Regoli E, Tofani M, Valente D, Fabbrini G, Fabbrini A, Ruggieri M, et al. Tools to assess the quality of life in patients with Parkinson's disease: a systematic review. Expert Rev Pharmacoecon Outcomes Res. 2021;21(1):55-68

25. Santos MP, da Silva BA, Ovando AC, Ilha J, Swarowsky A Comparison between two functional mobility scales for Parkinson's disease directly applied to physical therapy practice: cross-cultural adaptation and measurement properties. Eur J Phys Rehabil Med. 2017;53(5):664-75.

26. Simpson J, Lekwuwa G, Crawford T. Predictors of quality of life in people with Parkinson's disease: evidence for both domain specific and general relationships. Disabil Rehabil. 2014;36(23):1964-70.

27. Skorvanek M, Martinez-Martin P, Kovacs N, Zezula I, RodriguezViolan-te M, Corvol JC, et al. Relationship between the MDS-UPDRS and Quality of Life: A large multicenter study of 3206 patients. Parkinsonism Relat Disord. 2018:52:83-9.

28. Tu XJ, Hwang WJ, Ma HI, Chang LH, Hsu SP. Determinants of generic and specific health-related quality of life in patients with Parkinson's disease. PLoS One. 2017 Jun 26;12(6):e0178896.

29. Verheyden G, Kampshoff CS, Burnett ME, Cashell J, Martinelli L, Nicholas A, et al. Psychometric properties of 3 functional mobility tests for people with Parkinson disease. Phys Ther. 2014:94(2):230-9. doi: 10.2522/ ptj.20130141.

30. Xing F, Peng G, Liang T, Jiang J. Challenges for deploying iot wearable medical devices among the ageing population. In: Streitz N, Konom $\mathrm{S}$, editors. 6th International Conference DAPI, Held as Part of $\mathrm{HCl}$ International 2018; 2018 July 15-20; Las Vegas, USA. Switzerland: Springer Internationa Publishing; 2018. Proceedings, Part I. p. 286-95. https://www.springer.com/gp/ book/9783319911243 